\title{
Articles
}

\section{University Continuing Education Units: Agents for Social Change?}

\author{
Bob Cram, University of Saskatchewan \\ Dirk Morrison, University of Saskatchewan
}

\begin{abstract}
Many commentators have argued that Canadian university continuing education has gradually abandoned its historical commitment to social justice in educational programming in favour of a marketoriented approach. Although such literature clearly expresses a deeply-felt sentiment among continuing educators, it has tended to have two problems. First, many proponents of this view have not explained what they mean by social justice, which makes informed discussion of this issue difficult. Second, in praising historical adult education as a social justice movement, many commentators have neglected to provide coherent and pragmatic alternatives for the present. This article addresses these two problems by providing a dialogic theory of social justice,
\end{abstract}

\section{RÉSUMÉ}

Plusieurs commentateurs soutiennent que l'éducation permanente universitaire au Canada a abandonné graduellement son engagement historique pour la justice sociale en programmes d'études, et ceci en faveur d'une approche privilégiant le rôle du marché. Bien qu'une telle littérature exprime clairement un sentiment profondément ressenti parmi des éducateurs d'éducation permanente, elle semble démontrer deux difficultés. Premièrement, les promoteurs de cette perspective n'ont pas expliqué ce qu'ils entendent par la justice sociale, ce qui rend difficile des discussions informées sur cette question. Deuxièmement, dans la louange de l'ancienne éducation aux adultes comme mouvement de justice sociale, plusieurs commentateurs ont négligé de fournir 
derived from political philosophy, as a conceptual framework to examine ways in which a new understanding of social justice could be practically applied in both strategic and program planning for university continuing education. This conceptual framework is then used to guide and inform a discussion of how information and communications technologies (ICT) can be used by university-based continuing education units to develop and implement learning opportunities designed to empower persons and organizations working for social justice. des solutions cohérentes et pragmatiques actuelles. Cet article adresse ces deux difficultés en offrant une théorie dialogique de la justice sociale, une théorie dérivée de la philosophie politique, qui est le cadre conceptuel pour l'examen des façons par lesquelles une nouvelle compréhension de la justice sociale peut s'appliquer de façon pratique dans la planification stratégique et la planification des programmes en éducation permanente universitaire. Ce cadre conceptuel est ensuite utilisé pour orienter et informer une discussion sur l'utilisation des technologies de l'information et des communications (TIC) par des unités d'éducation permanente universitaire afin de développer et de mettre sur pied des occasions d'apprentissage conçues pour responsabiliser les personnes et les organismes travaillant pour la justice sociale.

\section{INTRODUCTION}

Judging from the literature (Alexander, 1997; Burbules \& Callister, 2000; Cruikshank, 1994; Haughey, 1998; Isley, 1992; Selman, 1994; Wilson \& Cervero, 2001), university continuing educators are divided between those who wish to respond to market demands and those who advocate a return to our social justice roots, what Selman (1985) called the "profession" and the "movement." This debate has been especially prominent in the Canadian Journal of University Continuing Education (Cruikshank, 1996, 1998; Cunningham, 1992; Hass, 1992; Karpiak \& Kops, 1995; Lamble \& Thompson, 2000; Lauzon, 2000; McLean, 1996; Selman, 1985; Stern, 1992). We believe that the issue is of central importance to Canadian university continuing educators, but that it is not as polarized as it first appears. The perceived division stems from a lack of clarity about what constitutes social justice. We hope, 
therefore, to achieve two things in this paper: first, to provide a functional description of social justice based on political theory and, second, to link that description to some pragmatic implications for current university continuing education practice.

Tovey's (1994) work suggested that continuing educators should not be surprised at how strongly the question of social justice concerns them. His study showed that most university continuing educators in the United Kingdom believed a social mission was more important than generating income, a view he found was not shared by continuing educators from the private sector and professional associations, who were motivated by the primary goals of corporate profitability or enhancing the reputation of their profession. Generally speaking, they also expected that, when collaborating with university continuing education units (CEUs), the CEU should simply deliver the product requested and not worry about fulfilling social missions. To the extent it can be transferred to the Canadian context, Tovey's study suggests that university continuing educators wish to be driven mainly by a social mission. It should not be surprising, therefore, if university CEUs feel pulled in two directions, that is, pursuing a social mission and meeting tougher revenue requirements.

If most university continuing educators support the idea of a social mission, why is there so much debate? Although some may argue Tovey's study is not relevant in the Canadian context, this seems doubtful given the historical role of Canadian university CEUs (e.g., the Antigonish Movement, the Canadian Association for Adult Education, and the Citizens' Forum). We suspect the problem lies elsewhere. First, these studies rarely explain what they mean by social justice. Accordingly, the apparent division among continuing educators may be less substantive than it appears, because they unknowingly talk about different things when they describe social justice. Second, appeals for a social justice reorientation often call for a renewal of the traditions of Canadian adult education and tend not to consider whether different approaches may now be required (Cruikshank, 1994, 1996; Lauzon, 2000; Selman, 1985). We suspect this fondness for past approaches leaves many contemporary continuing educators wondering how they might practically introduce a more socially just approach today. We focus on these two issues by providing a clearer picture of what constitutes social justice through insights from political philosophy and by attempting to give continuing educators some pragmatic approaches to incorporating social justice into their work.

Continuing educators must live and function within an environment that is increasingly market driven, even within the public sector (Gross Stein, 2001). One may dislike or celebrate consumerism and economic globalization, but one cannot escape them. That does not mean succumbing to them. "We are in danger of losing the idea that a future is created, bit by bit, out of 
our political desires and choices" (Kingwell, 2000, p. 221). How then does the CEU find a role that meets its need to be entrepreneurial and also serves a social mission that involves its university?

\section{What Do We Mean by Social Justice?}

It can be argued that we will find evidence for social justice both in the processes by which we plan educational programs and facilitate learning and in the products we provide as educational programs. The processes and the products of program planning are the most tangible aspects of our work. Over the last decade, Cervero and Wilson (1994; Wilson \& Cervero, 1996, $1997,2001)$ have argued that educational program planning is inherently political, part of a struggle for knowledge and power. "Simply put, adult education cannot be a neutral activity; if it were, why would anyone care about it? Therein lies educators' central responsibility-namely, what kind of world will their practice shape?" (Cervero \& Wilson, 1994, p. 5).

More fundamentally, how do educators know what is socially just? Until we answer this central question, we cannot answer Cervero and Wilson's questions. Social justice has too often been whatever an individual thinks it should be, which can lead to a slightly accusatory tone in at least some of the literature. In these instances, a reader sometimes feels unwillingly lumped into the group of those who do not care about social justice, even though social justice is never explained. Wilson and Cervero (2001) recognized this flaw, but papered over it: "Although there are some serious questions that might be raised around the often uncritical espousal of social justice, we nonetheless share the deep conviction that this is what adult education can and should be about" (p. 277). Perhaps so, but how do we achieve a more critically aware espousal of what is socially just? Does this mean, for example, that all corporate training is socially unjust and all citizenship education is just? Can we see social justice only in the product, or is it also in the process we use to plan our educational programs?

\section{Continuing Education Program Planning as Politics}

All education is intended to effect some change. Therefore, education must have some social and political effect regardless of what a program planner believes about his or her political role. This emphasis on education as change is self-evident: education that does not lead to change may not be education at all. Certainly, it is not effective education (Frankena, 1973). Consequently, responsible program planning requires that continuing educators engage with change-which has an inherently political dimension-and make strategic choices. They must ask who benefits and who should benefit and "to whom and for what are we responsible?" (Wilson \& Cervero, 2001, p. 269; 
also see Guinsberg, 1996). These questions force continuing educators to think consciously about values and to act politically in pursuing their goals. Wilson and Cervero (2001) spelled out the values they believe undergird responsible planning.

If we understand the foundations of adult education practice as the struggle for knowledge and power (not as "applied procedural expertise"), then strategic educational practice means political action that forthrightly attempts to alter who benefits in such struggles by seeking to redistribute benefits to those who should." (p. 274; italics added)

Theirs is one of the more explicit conceptions of something like social justice, but it still begs the questions: Who should decide the nature of the benefit and who will benefit? How are such decisions made? If such processes are not just, can there be responsible program planning? What if a program planner believes a program is socially just when the vast majority of citizens clearly would not? What if achieving a socially just goal leads a programmer to behave unjustly? Cervero and Wilson's widely accepted version of responsible planning does not address these possibilities and-when applied in some of the case studies they have relied upon-has led to program planning activities that are questionable on ethical grounds. Sork (1996) pointed out that in these instances "there is little discussion of the moral justification for actions that could easily be viewed as manipulative or antidemocratic" (p. 86). Here one sees the danger of espousing social justice without serious consideration of how to determine what constitutes social justice. If "responsible" program planning means pursuing an exclusively personal vision of social justice ends, then questionable means can be rationalized as just. If program planning is political, as Wilson and Cervero (2001) have argued, then perhaps a better approach to understanding social justice can be found in political theory. We believe that the conceptual framework for social justice that follows will help university continuing educators avoid the trap of a purely idiosyncratic view of social justice in university continuing education.

\section{The Need for New Approaches to Social Justice in Program Planning}

The debate about the political aims of adult and continuing education "... is so long standing now as to be beyond the patience of too many adult educators" (Wilson \& Cervero, 2001, p. 280). That may explain why some seem unwilling to debate the issue, while others argue vociferously for a return to university continuing education's historical roots of social justice. We believe the debate should not be ignored. Most Canadians live lives of relative privilege. It is too easy to take this for granted and ignore profound examples 
of injustice. However, it is equally easy to engage in polemical discussions rather than balanced ones. Perhaps many ignore the issue because some of the social justice literature itself seems irrelevant, even to those who support social activism. For example:

In literature concerning the future of social activism through university continuing education, there is a curious silence with regard to the need for radically new forms of activist practice. Even though we have recognized that the world is changing and that social activism through adult education is becoming more difficult to sustain, we have not yet adequately recognized that the connection between these two tendencies is inextricable and cannot be explained simply through institutional factors such as budget cutbacks, cost-recovery requirements, or the conservative machinations of university leaders and government funding agencies. The very changes that are making social activism difficult for us to sustain are creating patterns of domination that cannot readily be addressed through existing forms of activism. (McLean, 1996, p. 9)

Instead of looking for new forms of activism, many social justice proponents analyze the causes of the perceived lack of activism, usually blaming it on funding cuts, economic globalization, or the professionalization of adult education (Collins, 1992; Cruikshank, 1994, 1996; Lauzon, 2000; Selman, 1985). It is also easy to see how arguments about the commoditization of education (Noble, 2001), especially distance education, could be applied to large parts of a university continuing education enterprise. Like McLean (1996), Haughey (1998) pointed out that our field needs to look for new theoretical underpinnings, arguing that it is time for adult educators to confront complex social issues through intellectual regeneration, achieved by borrowing from new theoretical approaches.

We agree that social justice is important, but how do continuing educators conceptualize it in a way that might bridge the perceived divide between the professional and social activist approaches? How do they get beyond their personal views about its nature? Following Haughey's (1998) advice to look to new theoretical approaches-and McLean's (1996) and Welton's (2002) examples of that-we have turned to political philosophy. If Cervero and Wilson (1994; Wilson \& Cervero, 1996, 2001) are correct in their widely accepted view that program planning is a political process, then political philosophy should offer some assistance in delineating a contemporary and relevant perspective of the social justice imperative in adult and continuing education programming. 


\section{A Dialogic Theory of Social Justice}

For the last three decades, since the publication of John Rawls' A Theory of Justice (1971), debates about what constitutes a just society and how social justice is connected to individual pursuits have been central concerns of political philosophers (Nussbaum, 2001; Richardson \& Weithman, 1999). A full explanation of Rawls' ideas about justice, let alone the debate that has ensued, is well beyond the scope of this article. ${ }^{1}$ Suffice it to say here that Rawls is the leading exponent of the liberal school, and many commentators have been critical of the liberals' impractical and excessively individualistic approach to explaining how we know what is just. As Gray (1992) and Kingwell (1995) pointed out, even if philosophically powerful, such theories seem to have little pragmatic application. Their abstract procedural rules for objectivity seem impossibly idealistic and unlikely to motivate real people in real situations. Moreover, in a postmodern, globalized world, the liberal school's rationalist roots in the Western world view cannot give its theories the universal application they attempt to claim. In fact, political philosophy has been in something of a state of crisis for the past few decades, due in part to the effects of postmodern theory and a more interdependent, globalized world. For these reasons, Western thinking about social justice, derived largely from Kant and the utilitarians, seems to have lost much of its power.

As Kingwell (1995) explained, new, more unified theoretical approaches to thinking about social justice have been developing - in response to criticism of the liberal approach - that draw on the strengths of postmodern, communitarian, and liberal theories, while discarding their weaknesses. These approaches are beginning to move beyond the ideologies of their proponents and sometimes make for strange bedfellows. For example, Habermas (1995; also see Rawls, 1995) waded in from the left in support of Rawls and the liberal view. These particular approaches, regardless of the political leanings of the theorist, share one thing in common: an orientation to the process of dialogue itself as central to social justice. In other words, we may be able to arrive at some tentative agreements about social justice, even across differing ideologies and cultures, if we recognize that social justice resides less in the products of our continuing education programs and more in the processes we follow to create those programs. We can agree that the "product" is still of importance. For example, a training program in public relations skills for corporate $\mathrm{CEO}$ s is going to do less for social justice than a literacy program for the homeless. However, continuing educators do need to focus more on process as one of the most important, perhaps the single most important, determinants of social justice. As mentioned before, much current political theory looks to dialogic processes for evidence of social justice.

Kingwell (1995) is one Canadian theorist who has attempted to pull the various theoretical threads together to put forward his own theory of dia- 
logic justice based around his notion of civility. Kingwell's "civility" is not a minor virtue of manners or politeness, but a major virtue of citizenship and an essential component of social justice and democracy. Dialogic theories like his locate social justice within processes that we use to legitimate what is just, and not within particular ideological or political ends. In other words, in a postmodern, globalized world where agreement is difficult, it is better to judge whether social change is progressive by the processes we follow in determining what social change we want, rather than by judging the particular change in isolation as a "product." This requires that social justice be redefined according to group ends that are arrived at by a just process (Kingwell, 1995). Although Kingwell is a political philosopher, support for this orientation to dialogue can be found within the adult and continuing education literature and among those whom most would label as social justice advocates. Welton (2002), for example, has underscored the importance of dialogue and listening in program planning. Cervero and Wilson's (1994; Wilson \& Cervero, 1996, 2001) emphasis on understanding "responsible" program planning as a socio-political process of negotiation was also an orientation toward dialogue. Freire (1970) is one of the most eloquent and well-known social activist defenders of the centrality of dialogue to adult education. He has warned how easy it is for radical educators to fall into the trap of promoting their own views, ignoring true dialogue, and engaging in a top-down "banking" approach to program planning. To counter such propensities, Freire reminded educators: "It is not our role to speak to the people about our own view of the world, nor to attempt to impose that view on them, but rather to dialogue with the people about their view and ours" (p. 86).

In fact, such dialogic processes are not far removed from the social justice traditions of Canadian adult education. One of the most distinctive features of the Antigonish Movement was the study club where people would gather in one another's homes for discussion (Alexander, 1997). The Citizens' Forum used radio as a means of involving rural people in discussion groups about political issues and helping them to become more articulate and involved citizens (Faris, 1975; Selman, 1995a, 1995b; Selman, Cooke, Selman, \& Dampier, 1998). It was the power of a process that involved dialogue amongst members of the learning community, not ideology, that gave these movements their relevance and capacity to elicit change. The notion of social justice as an outcome of dialogical processes, therefore, has been used in the most wellknown of Canadian adult education programs that sought social change. More recently, Welton (2002) has made a compelling argument similar to our focus on dialogue, although his interest was primarily with listening, which is one critical element of dialogue. "I want to break the concept of listening out of the programme planners' classroom by arguing that listening ought to be in the foreground of our thinking about how deliberative democracy 
works" (p. 198). A greater focus on dialogue may help to bridge the so-called divide between what Selman (1985) called the social reformers and the professionals in university continuing education.

Kingwell's (1995) dialogic justice process, although based on a complex philosophical analysis, is simple and pragmatic in its application. Like similar dialogic approaches to justice, it provides a strengthened theoretical underpinning for Freire's influential work. Unlike liberal theorists, Kingwell accepted that dialogic processes cannot be objective or individual. Further, it is not just a matter of legalistic rights, but also what we deem in our hearts to be the good, that is, what is moral. Our views about the good, in turn, emanate from the traditions of our group(s), our community, and represent our underlying moral commitments. Kingwell claimed that in order to engage in reasoned and principled dialogue we must hold these views in check, without giving them up, when we move from the personal to the public realm. Fundamental disagreements about the good (e.g., abortion, capital punishment) inhibit real dialogue. The dialogic process requires that we take difference seriously by showing restraint about our views of the good and by subjecting our own group's ideas to constant self-critique based on the ideas of other groups. Most university continuing educators would claim they engage in dialogue with learners and their communities all the time, but Kingwell's notion of civil dialogue is one of purposeful, intentional, reflective dialogue that goes well beyond mere discussion or advisory committees.

Kingwell's dialogic approach is similar in some respects to Schön's (1983) call for reflective practice, Welton's (2002) call for listening in adult education, and Freire's (1970) dialogics, but with a greater emphasis on group self-critique and on civility. Such civility is more than mere politeness and is achieved through dialogue and discussion that must be rational and constrained in some ways, even if that departs from strict truth-telling. To use an example from Kingwell (1995), if an individual asks what one thinks of his new suit, how many would tell him it is ugly? Any person who engaged in such blatant truth-telling on a continuous basis would be regarded as deranged. In such cases, restraint for the sake of civility is not a failure of character, but part of our role as social beings. It is a critical ingredient of all dialogue in that it permits a continuation of the discussion. As Kingwell (1995) summed up:

Thus nondeceitful yet civil dialogue becomes the nexus of decisionmaking about society's basic structure. This is constrained dialogue, true, but the constraints can be justified by reference to pragmatic commitments we all perforce share: the need to inhabit a common social space while maintaining as many of our diverse personal and group commitments as such commonality will allow. It is, moreover, dialogue constrained not by strangely external means imposed from without, but 
rather on the basis of social practices that we all, to the degree we are citizens of a single society, take for granted. (pp. 223-224)

Therefore, a just dialogic process needs to combine rationality, self-critique (individually and within our group), and civility.

Civility, in this sense, is an ethical disposition that focuses on listening sensitively in order to understand (Kingwell, 1995; also see Welton, 2002) and on not saying all one could say. Its goal is to achieve understanding through conversation by practising self-restraint about one's own claims and by cultivating an ability to interpret and discern the force in the claims of others. In this sense, civility is hermeneutic. It aims for understanding and genuine openness to the views of others, which does not necessarily entail agreement or selling out one's own beliefs. Such dialogic processes of rationality, self-critique, and civility constitute social justice. They need not govern all interactions, but they should govern those in the public realm, which means continuing educators should use Kingwell's (1995) concept of dialogic justice in their professional roles. In that way, they can avoid taking purely personal positions about what constitutes social justice and rely instead on insights into social justice that come from the views of others and are based on processes of rational, self-critical, and civil dialogue.

How, then, do continuing educators give pragmatic meaning to such theory in their professional activities?

\section{Agents of Change: IMPlications for CEUs}

For many, the current environment of economic globalization, market-driven education, and privatization of public goods seems foreign and unpalatable, but another perspective may be in order. Threats can be opportunities. The current pressures facing institutions of higher education, especially continuing education, may act as a sort of incubator for universities that will be better adapted to meet the demands of the future. University CEUs should endeavour to be at the forefront of some of these changes, helping to guide their institutions into socially responsible choices. At the same time they must fight against the trend to constantly increasing revenue recovery, which makes all but profitable programs impossible.

Some would characterize CEUs as the "proprietaries of the university," but university continuing educators' desire for a social mission makes them different from for-profit continuing educators (Tovey, 1994). It is likely that flexible adult, community, professional, distance, and continuing education for the general public would be ignored by most universities were it not for CEUs that treat it as their primary mandate. Despite frequent demands from many senior university managers that CEUs recover all of their costs, 
university-based CEUs are still able to carry out their mandates within the context of the university environment in order to provide a critical interface with the larger community. This protects CEUs somewhat from a purely profit orientation and provides them with a significant advantage and niche in any competition with the for-profit world. We would argue that universities need CEUs' help to adapt to many of today's pressures (e.g., online learning) and to keep themselves rooted in some sense of social mission. Dialogic processes, especially in program and strategic planning, can help CEUs avoid becoming mere profit-oriented clones of the private sector. True community-based dialogue can also build allies for CEUs in their struggle to maintain base-budget support from the larger university.

\section{Strength in a Dialogic Approach to Social Justice}

Education, as we have argued, is inherently political, because its purpose is to effect change. Ignoring the socio-political dimension not only avoids the self-critique called for by reflective practice and dialogic justice processes, but is also out of touch with changing political realities. In the early 1990s, Canadians barely mentioned social issues in the annual Maclean's magazine survey about the most important problems facing the country. By 1996, 11\% of Canadians were citing social issues as important, and by 2000, it had risen dramatically to 50\% (cited in Gross Stein, 2001, p. 62). Although this had fallen to $36 \%$ by 2002, Canadians still thought such issues were by far the most important matter facing the country, with second place going to unemployment and the economy, which were selected by only $14 \%$ of respondents (Maclean's, December 30, 2002, to January 6, 2003).

In this context, CEUs have historical strengths that are more relevant than ever. Although it is a challenging time, university continuing educators can position themselves as the community-university interface and as guides for their institutions, as universities attempt to respond to new adult learner and government demands for enhanced learning opportunities. This need not have a technical-rational decision-making bias (Jarvis, 1999; Schön, 1983). It can be rational, reflective, and civil in Kingwell's (1995) sense, and thereby it becomes socially just.

Therefore, our first and overarching recommendation for practical strategies to bridge the divide between professional and social justice models is that, at the macro level, each CEU needs to take seriously the kinds of processes it uses for program and strategic planning. Cervero and Wilson (1994; Wilson \& Cervero, 1996, 1997, 2001) have been instructive in redirecting the attention of adult educators to the degree to which their program planning entails negotiating power and interests among individuals and groups. This emphasis can be expanded to include strategic planning. CEUs need to establish processes that specifically allow for serious, meaningful, and rational 
self-critique and civil dialogue with their stakeholders, including those with opposing views, and within their units at both the strategic and program planning levels. Such dialogic processes, which in themselves constitute a large part of social justice, should also be integral parts of any of the other suggestions we make below. In fact, in one sense we could end our suggestions here. A serious commitment to the dialogue of civility within an institution's local communities and external groups would, we believe, constitute a large commitment to social justice and lead to increased "socially just products" (not just processes) in the form of programs that promote social reform and social change. This being said, we now turn our attention to speculations regarding a perhaps unlikely conduit for empowering CEUs and the wider university to better fulfill their social mission, namely, information and communication technology (ICT). In fact, communications technologies, like dialogue, have long been used to foster social justice in Canadian adult education. Gordon Hawkins, then associate director of the Canadian Association for Adult Education (CAAE), wrote a piece in 1954 describing how Canadian adult education differed from the more elitist approaches seen in Britain. He noted:

With newly formed and changing communities, with immigrant groups, with the awful challenge of distance, methods and aims are bound to be different. But there is also a newer, consciously evolved philosophy of adult education. It stems from a deep concern with the processes of democracy - with how the individual and the group and the community work, as much as with what they set out to achieve. Hence the emphasis in their scheme of things on group work, community organisation, discussion methods and techniques, leadership courses and so on, and, as a background to all that, on the use of mass media to spread a common basis of information for their discussion and their social actions. (p. 2; also see Selman et al., 1998, p. 44)

\section{University CEUs as Change Agents}

The university's historical reliance on an information-transfer approach to pedagogy (e.g., the lecture), with its inherent perpetuation of student passivity and dependence, is slowly being displaced by new approaches to teaching and learning. These, in turn, have been driven by a number of factors (e.g., increasing competition, funding pressures, changing student demographics and expectations), not the least of which is rapid advancements in sophisticated information and communication technologies (e.g., the Internet, the WWW).

Historically, university-based CEUs have been early adopters of information and communications technologies (e.g., Magic Lanterns, film strips, 
radio, television, the Internet), using them to deliver high-quality education to local and/or dispersed learners. These CEUs have had and continue to have significant advantages in this regard. Due to the risk inherent in what Archer, Garrison, and Anderson (1999) regarded as the disruptive technologies (i.e., technologies that begin in emerging or insignificant markets, often fail, and are initially embraced by a business' least profitable customers), universities have avoided them. However, as these authors pointed out, while large companies avoid them, a small unit within a company may adopt them if given sufficient flexibility to innovate. Such is the case with university-based CEUs. Universities are wise to encourage the use of such technologies in these smaller units so that the larger whole is somewhat protected from too much risk, but still able to glean the benefits of rapid adoption and adaptation of so-called disruptive technologies. This strategy can be identified within the current boom in ICT-based higher and continuing educational opportunities. Initially, many CEUs rapidly adopted these technologies (e.g., computer conferencing) to improve service to students and learners at a distance. In turn, as many of these technologies were adapted to serve the needs of learners, they forced continuing educators to rethink their approach to pedagogy. Consequently, CEUs often lead the way for their universities, not only in applying a variety of technological innovations, but also in developing new approaches to teaching and learning. We believe that it is just such activities that are slowly but surely influencing the larger university community to respond with their own courses and programs using ICT (e.g., online courses). It is clear, as Archer et al. (1999) discuss more generally, that CEUs are incubators of change for their university. We underscore the point that through the early adoption of ICT and the innovative adaptation of these to educational programming, CEUs move the wider university community in new and exciting directions. As laudable as this might be, however, we would argue that it is time for university-based CEUs to manage and guide these activities and innovations as a conscious and deliberate strategy, rather than as a knee-jerk reaction to factors and pressures from within and without the university context. In other words, it is time to move beyond being incubators for change to become conduits for change. One such strategy is for CEUs to take a leadership role in the adoption and adaptation of ICT for the purposes of social justice.

\section{Using Information and Communication Technologies for Social Justice}

A research report entitled Audit of ICT Initiatives: In Social Inclusion Partnerships and Working for Communities Pathfinders in Scotland (Gilliatt, MacLean, \& Brogden, 2000) focused on initiatives that promote the use of 
information and communication technologies as a means of encouraging and promoting social inclusion. The authors claim

the imaginative and effective use of ICT to help people to participate more effectively in their communities, or to overcome the problems of remoteness or isolation, can be vital elements in achieving the Government vision of achieving "a Scotland where everyone both contributes to and benefits from, the community in which they live." It identifies the key to achieving this objective as "tackling the problems of disadvantage, isolation, lack of opportunity or difficulty in accessing the opportunities that are available." (p. 1)

In terms of the potential for ICT to enable social justice goals, the report identified a list of potential benefits from the provision of ICT in the community. ICT in communities can

- provide access to, or share a wide range of information;

- provide access to, or allow the development of new skills (social, communication, technical);

- enable potentially excluded groups (including people with disabilities, ethnic minorities, lone parents, etc.) to participate more fully in education, employment, leisure, etc.;

- enable public organizations such as local authorities to deliver information and services more easily or effectively;

- enable people to participate more fully in the democratic process;

- enable access to learning from a variety of places, not just schools and colleges, and create a greater equality of access between urban and rural areas; and

- enable people to work from a range of places, enabling more people to enter the workforce. (p. 2)

Although this study focused on the efforts of a large-scale government initiative to implement, monitor, and evaluate the impacts of ICT on social justice goals, we believe that individual university-based CEUs can also make explicit the value of using information and communication technology (ICT) in promoting social justice. This can be achieved by the innovative adaptation of ICT to continuing education programming for the following purposes.

First and foremost, CEUs should strive for social justice by using ICT to empower individuals, community support agencies, and educational institutions. For example, by encouraging coordination, co-operative partnerships, dialogue, and communication between educational service providers, ICT can foster social justice. A simple way would be for CEUs to increase the value and ease of use of community and education services through the pro- 
vision of accurate and current information to end users. This readily available information can, in turn, enhance dialogue, co-operation, and coordination between individuals and agencies engaged in social justice initiatives, as well as help minimize duplication in education service delivery, and thereby enhance efficiency and effectiveness for all.

Another way that CEUs can fulfill their social mission by using ICT, and the potential dialogic processes inherent in such technology, is to target and mount specific community needs for information technology skills development. If CEUs delivered well-designed education and training programs focused on ICT, they could raise the knowledge and competence in the use of information technology for social justice purposes, especially among those who need it the most, the marginalized. Such knowledge and competence would, in turn, affect the efficiency and effectiveness of persons and organizations working within the community sector to design and deliver social justice educational programming. This is not trivial. In our view, increasing competence in workers' or an organization's ability to use information technology has potential to enhance the democratic process. It does this by facilitating the engagement of communities of interest in active, serious, meaningful, and rational self-critique and civil dialogue via the conduit of ICT (e.g., online community networks). The adoption and adaptation of these technologies have tremendous potential to empower social justice initiatives. In addition, by tapping into these online communities and networks, various levels of government are better able to consult the public interest and therefore adjust policy accordingly. This is the essence of the goals of social justice.

Although a number of other strategies could be articulated, the university-based CEU, because of its unique configuration, context, and mandate, is often well situated to use powerful new tools, such as those embedded within ICT, to foster reflective, rational, and civil dialogue between and among community members for the explicit purposes of articulating socially just products and processes.

Finally, if CEUs are to be successful in adopting an educational strategy that focuses on ICT as a primary conduit of dialogical processes for the purposes of socially just initiatives, they will need to

- establish and maintain partnerships with individuals, organizations, agencies, and community groups involved in social justice initiatives and educational programming;

- provide an educational solution to community groups' needs for training in using ICT for a variety of purposes, including social justice;

- provide support for professional development in ICT and its applications among relevant CEU staff; 
- build and make widely available continuing education information systems, systems that are designed to be of high value for members of the wider community, not just for marketing purposes (see http://www. infoxchange.net.au/index.html); and

- evaluate actively, then promote the CEU's capacity to address relevant education and training needs regarding ICT and social justice initiatives.

Our emphasis here on the power of ICT to realize the goals of social justice within the educational mandate of university-based CEUs is important. By using the tools embedded within ICT and by connecting with other knowers, people involved in social justice activities are able to "sharpen and extend their knowledge by taking the stances or viewpoints of others within a community of inquiry" (Hickman, 2001, p. 48). The importance of this exchange and interchange between people with similar contexts and interests (e.g., social justice) is pivotal as "thinking, language, and knowledge are all community enterprises, both in terms of their historical development and in terms of their ongoing function of construction and reconstruction" (Hickman, 2001, p. 48). We believe that CEUs have a responsibility to work with the wider community and its constituents to bring the benefits of ICT to all. Further, they have a responsibility to ensure that the advantages of using this technology for the purposes of social justice are recognized and enabled in the relevant community sectors to the benefit and empowerment of the otherwise disenfranchised. The ultimate goal of such efforts is to enable people to make informed decisions and initiate actions, through dialogical processes, to change the circumstances in which they find themselves.

\section{CONCLUSION}

Have CEUs abandoned their commitment to social justice? Based on our conception of social justice, that question could only be answered by conducting research on the processes used by CEUs to plan their strategic goals, articulate their values, and deliver their educational programs. The point of this article has been to reframe the debate by offering an alternate view of social justice and suggesting just a few possible, practical options that might foster social justice. We hope that our conceptual model-focusing as it does on a spirit of group self-critique and civil, rational discussion-invites more discussion. Until now, social justice in our field has tended to mean ideological positions rather than what contemporary political philosophers would think of as social justice. We hope that our attempt to think of social justice as a dialogic process and not just as a product can be used for theoretical discussion, practical program planning, and continuing education management. 
CEUs, and the universities of which they are an integral part, face enormous pressures for change from student demographic trends, financial constraint coupled with increasing demands for accountability, rapid developments in information technology, globalization, and new, profit-oriented competitors. In the face of these forces, it may appear even more difficult to maintain any semblance of a social mission in university continuing education. However, an overarching strategy of utilizing dialogic social justice processes in the planning, management, and delivery of continuing education programs may counter these forces working against social justice as a priority in university-based CEUs.

Historically, university-based continuing educators have been engaged as social activists and educational programmers in activities critical to the evolution of higher education. CEUs ought not to rest on their laurels but should strive to remain at the cutting edge of educational innovation and service to society; collectively, we must simultaneously look inward and outward for new possibilities for integrating social justice into our programming priorities. Current innovations in the development and delivery of educational offerings, especially those utilizing and emphasizing appropriate information and communication technologies for social justice purposes, place CEUs in a unique situation within the university, one ripe with opportunity. Straddling the worlds of the entrepreneur and the academic, the social activist and the professional, we can lead the way with an approach to higher and continuing education that is both contemporary and just. 


\section{REFERENCES}

Alexander, A. (1997). The Antigonish movement: Moses Coady and adult education today. Toronto: Thompson.

Archer, W. (1999). Virtual content villages versus administrative city states. In Canadian Association for University Continuing Education 1999 Conference Papers, 1-9.

Archer, W., Garrison, R., \& Anderson, T. (1999). Adopting disruptive technologies in traditional universities. Canadian Journal of University Continuing Education, 25(1), 13-30.

Burbules, N. C., \& Callister, T. A., Jr. (2000). Universities in transition: The promise and the challenge of new technologies. Teachers College Record, 102(2), 271-293. Retrieved February 12, 2003, from http://www.tcrecord. org/Content.asp?ContentID $=10362$

Cervero, R. M., \& Wilson, A. L. (1994). Planning responsibly for adult education. A guide to negotiating power and interests. San Francisco: Jossey-Bass.

Collins, M. (1992). Adult and continuing education should resist further professionalization. In R. G. Brockett (Series Eds.), A. B. Knox (Consulting Ed.), \& M. W. Galbraith \& B. R. Sisco (Vol. Eds.), New Directions for Adult and Continuing Education, 54: Confronting controversies in challenging times: A call for action (pp. 37-43). San Francisco: Jossey-Bass.

Cruikshank, J. (1994). Cost-recovery: The current challenge. In M. Brooke \& M. Waldron (Eds.), University continuing education in Canada (pp. 74-83). Toronto: Thompson.

Cruikshank, J. (1996). Economic globalization: A need for alternative visions. Canadian Journal of University Continuing Education, 22(1), 49-66.

Cruikshank, J. (1998). Are we aiding the enemy? Adult education in the global economy. Canadian Journal of University Continuing Education, 24(1), 101-113.

Cunningham, P. (1992). University continuing educators should be social activists. Canadian Journal of University Continuing Education, 18(2), 19-25.

Faris, R. (1975). The passionate educators: Voluntary associations and the struggle for control of adult educational broadcasting in Canada, 1919-1952. Toronto: Peter Martin Associates Ltd.

Frankena, W. K. (1973). Education. In P. P. Wiener (Ed.), Dictionary of the history of ideas: Studies of selected pivotal ideas, Vol. 2 (pp. 71-85). New York: Charles Scribner's. 
Freire, P. (1970). The pedagogy of the oppressed. (M. Bergman Ramos, Trans.). New York: Herder and Herder. (Original work published 1968)

Gilliatt, J., MacLean, D., \& Brogden, J. (2000). Audit of ICT initiatives: In social inclusion partnerships and working for communities pathfinders in Scotland. Lambda Research and Consultancy Limited, The Scottish Executive Central Research Unit. Retrieved January 2003 from http://www.scotland.gov.uk/cru/kd01/red/audit04.htm

Gray, J. (1992, July 3). Against the new liberalism: Rawls, Dworkin, and the emptying of political life. Times Literary Supplement, 13-15.

Gross Stein, J. (2001). The cult of efficiency. Toronto: Anansi.

Guinsburg, T. N. (1996). Efficient, effective and ethical practice in lifelong learning. Canadian Journal of University Continuing Education, 22(1), 66-75.

Habermas, J. (1995). Reconciliation through the public use of reason:

Remarks on John Rawls' political liberalism. The Journal of Philosophy, 92(3), 109-131.

Hass, G. (1992). Entrepreneurial education-A paradigm shift. Canadian Journal of University Continuing Education, 18(2), 27-35.

Haughey, D. (1998). From passion to passivity: The decline of university extension for social change. In S. M. Scott, B. Spencer, \& A. M. Thomas (Eds.), Learning for life: Canadian readings in adult education (pp. 200-212). Toronto: Thompson.

Hawkins, G. (1954). As others see us. Food for Thought, 14(8), 2-8.

Hickman, L. A. (2001). Philosophical tools for technological culture: Putting pragmatism to work. Bloomington: Indiana University Press.

Isley, P. J. (1992). The undeniable link: Adult and continuing education and social change. In R. G. Brockett (Series Eds.), A. B. Knox (Consulting Ed.), \& M. W. Galbraith \& B. R. Sisco (Vol. Eds.), New Directions for Adult and Continuing Education, 54: Confronting controversies in challenging times: A call for action (pp. 25-34). San Francisco: Jossey-Bass.

Jarvis, P. (1999). The practitioner-researcher: Developing theory from practice. San Francisco: Jossey-Bass.

Karpiak, I., \& Kops, B. (1995). Towards a new continuing higher education: Listening to the subtle signals of change. Canadian Journal of University Continuing Education, 21(2), 39-54.

Kingwell, M. (1995). A civil tongue: Justice, dialogue, and the politics of pluralism. University Park, PA: Pennsylvania State University Press. 
Kingwell, M. (2000). The world we want: Virtue, vice and the good citizen. Toronto: Penguin.

Lamble, W., \& Thompson, G. (2000). Reconceptualizing university extension and public service: A response to Lauzon. Canadian Journal of University Continuing Education, 26(2), 111-121.

Lauzon, A. C. (2000). University extension and public service in the age of economic globalization: A response to Thompson and Lamble. Canadian Journal of University Continuing Education, 26(1), 79-95.

Maclean's (2002, December 30 to 2003, January 6) 115(52) to 116(1). Maclean's Annual Poll, p. 35.

McLean, S. (1996). Continuing education and the postmodern arts of power. Canadian Journal of University Continuing Education, 22(2), 7-26.

Noble, D. (2001). Digital diploma mills: The automation of higher education. New York: Monthly Review Press.

Nussbaum, M. (2001, July 20). The enduring significance of John Rawls. Chronicle of Higher Education, B7-B9.

Rawls, J. (1995). Political liberalism: Reply to Habermas. The Journal of Philosophy, 92(3), 132-180.

Rawls, J. (1999). A theory of justice (Rev. ed.). Cambridge, MA: Belknapp.

Richardson, H. S., \& Weithman, P. J. (1999). Series introduction. In H. S. Richardson \& P. J. Weithman (Series Eds.) \& H. S. Richardson (Vol. Ed.), The philosophy of Rawls: A collection of essays. Vol. 3, Opponents and implications of A Theory of Justice (pp. vii-viii). New York: Garland.

Schön, D. A. (1983). The reflective practitioner. New York: Basic Books.

Selman, G. (1985). The adult educator: Change agent or program technician? Canadian Journal of University Continuing Education, 11(2), 77-86.

Selman, G. (1994). Continuing education and the Canadian mosaic. In M. Brooke \& M. Waldron (Eds.), University Continuing Education in Canada (pp. 4-18). Toronto: Thompson.

Selman, G. (1995a). Adult education and citizenship. In Adult Education in Canada: Historical Essays (pp. 73-84). Toronto: Thompson.

Selman, G. (1995b). The Canadian Association for Adult Education in the Corbett years: A re-evaluation. In Adult Education in Canada: Historical Essays (pp. 119-149). Toronto: Thompson.

Selman, G., Cooke, M., Selman, M., \& Dampier, P. (1998). The foundations of adult education in Canada (2nd ed.). Toronto: Thompson. 
Sork, T. (1996). Negotiating power and interests in planning: A critical perspective. In R. G. Brockett \& S. Imel (Series Eds.), A. B. Knox (Consulting Ed.), \& R. M. Cervero \& A. L. Wilson (Vol. Eds.), New Directions for Adult and Continuing Education, 69: What really matters in adult education program planning. Lessons in negotiating power and interests (pp. 81-90). San Francisco: Jossey-Bass.

Stern, M. (1992). University continuing educators should be entrepreneurs. Canadian Journal of University Continuing Education, 18(2), 19-25.

Tovey, P. (1994). Quality criteria in continuing professional education. An analysis. London: Routledge.

Welton, M. (2002). Listening, conflict and citizenship: Towards a pedagogy of civil society. International Journal of Lifelong Education, 21(3), 197-208.

Wilson, A. L. \& Cervero, R. M. (1996). Learning from practice: Learning to see what matters in adult education. In R. G. Brockett \& S. Imel (Series Eds.), A. B. Knox (Consulting Ed.), R. M. Cervero \& A. L. Wilson (Vol. Eds.). New Directions for Adult and Continuing Education, 69. What Really Matters in Adult Education Program Planning: Lessons in Negotiating Power and Interests (pp. 91-99). San Franciso: Jossey-Bass.

Wilson, A. L., \& Cervero, R. M. (1997). The song remains the same; The selective tradition of technical rationality in adult education program planning theory. International Journal of Lifelong Education, 16, 84-108.

Wilson, A. L., \& Cervero, R. M. (2001). Power in practice: A new foundation for adult education. In R. M. Cervero, A. L. Wilson, \& Associates (Eds.), Power in practice: Adult education and the struggle for knowledge and power in society (pp. 267-287). San Francisco: Jossey-Bass.

\section{ENDNOTE}

1. Richardson AND WEITHM AN (1999) REP ORIED THAT OVER 3,000 ARIICIES HAVE BEEN P UB LSHED ON RAWIS' THEORY OF JUSTICE, M ANY OF THEM CRITICAL RAWIS, HOWEVER HAS HARDLY BEEN A STATIC THINKER HIS M OST SIGNIFCANT WORK, A Theory of Justice, which was first published in 1971, was published again (1999) in a revised edition in which he refined and updated his thinking in response to some of the criticisms of the first edition. Readers interested in an overview of the main ideas of the competing theories can find a good discussion in Kingwell (1995). 


\section{BIOGRAPHIES}

Bob Cram is acting director for Extension Credit Studies and an assistant professor at the University of Saskatchewan Extension Division. Bob received his $\mathrm{PhD}$ in international history from the London School of Economics and his bachelor's and master's degrees from the University of Saskatchewan. His current research interests include adult education history, program planning theory, and computer mediated conferencing in online courses. He is a past-president of the Canadian Association of University Continuing Education (CAUCE).

Bob Cram est profeseur adjoint et directeur par intérim des Études créditées avec la Division de formation permanente à l'Université de la Saskatchewan. Bob a reçu son doctorat en histoire internationale du London School of Economics, et son baccalauréat ainsi que sa maîtrise de l'Université de la Saskatchewan. Ses intérêts actuels de recherche comprennent l'histoire en éducation aux adultes, la théorie de la planification de programmes et la téléconférence informatisée dans des cybercours. Il est un président sortant de l'Association pour l'éducation permanente dans les universités du Canada (AÉPUC).

Dirk Morrison is an associate professor with the Extension Division, University of Saskatchewan. He is a member of the Centre for Distributed Learning and the Instructional Design Group. His research interests include investigating factors influencing the facilitation of higher order thinking skills in online learning environments.

Dirk Morrison est professeur agrégé avec la Division de formation permanente à l'Université de la Saskatchewan. Il est membre du Centre d'apprentissage échelonné et du Groupe de conception de matériel pédagogique. Ses intérêts de recherche comprennent l'enquête sur les facteurs influençant la facilitation des processus mentaux de niveau élevé dans des milieux d'apprentissage électronique. 